\title{
ICT Use, Digital Skills and Students' Academic Performance: Exploring the Digital Divide
}

\author{
Adel Ben Youssef ${ }^{1, *(\mathbb{C}}$, Mounir Dahmani ${ }^{2} \mathbb{D}$ and Ludovic Ragni ${ }^{1}$ \\ 1 GREDEG CNRS, Université Côté d'Azur, 5 rue du 22ème BCA, 06300 Nice, France; \\ ludovic.ragni@univ-cotedazur.fr \\ 2 Higher Institute of Business Administration, University of Gafsa, Sidi Ahmed Zarroug, Gafsa 2112, Tunisia; \\ mounir.dahmani@isaeg.u-gafsa.tn \\ * Correspondence: adel.ben-youssef@univ-cotedazur.fr
}

Citation: Ben Youssef, A.; Dahmani, M.; Ragni, L. ICT Use, Digital Skills and Students' Academic Performance: Exploring the Digital Divide. Information 2022, 13, 129. https:// doi.org/10.3390/info13030129

Academic Editor: Michael Kerres

Received: 28 January 2022

Accepted: 2 March 2022

Published: 3 March 2022

Publisher's Note: MDPI stays neutral with regard to jurisdictional claims in published maps and institutional affiliations.

Copyright: (C) 2022 by the authors. Licensee MDPI, Basel, Switzerland. This article is an open access article distributed under the terms and conditions of the Creative Commons Attribution (CC BY) license (https:// creativecommons.org/licenses/by/ $4.0 /)$.

\begin{abstract}
Information and communication technologies (ICTs) are an integral part of our environment, and their uses vary across generations and among individuals. Today's student population is made up of "digital natives" who have grown up under the ubiquitous influence of digital technologies, and for whom the use of ICT is common and whose daily activities are structured around media use. The aim of this study is to examine the impact of ICT use and digital skills on students' academic performance and to explore the digital divide in France. Data were collected through face-to-face questionnaires administered to 1323 students enrolled in three French universities. Principal component analysis, a non-hierarchical k-means clustering approach and multilevel ordered logistic regression were used for data analysis and provide four main findings: first, poor investment in ICT affects students' results; second, the ICT training offered by universities has little impact on students' results; third, student performance improves with the innovative and collaborative use of ICTs; fourth, the acquisition of digital skills increases students' academic performance. The results show that the digital divide still exists, and this raises questions about the effectiveness of education policies in France. They suggest also that organizational change in universities is essential to enable an exploitation of ICT.
\end{abstract}

Keywords: higher education; ICT; digital skills; digital divide; academic performance of students

\section{Introduction}

Nowadays, students are at the center of all learning processes, and almost all education policies recommend a learner-centered approach with teachers fulfilling specific pedagogical functions. Information and communication technologies (ICTs) are affecting education at all levels, including higher education and most economic sectors. New learning and teaching tools have been developed and students are now learning in Internet-enabled environments. Thus, the learning environment is undergoing several transformations. ICTs are promoting profound changes to university teaching [1-3] and encouraging the use of diversified approaches, with measures aiming to increase flexibility related to administrative tasks and the modular organization of universities. The adoption of ICTs by the university sector has made it possible to modify teaching methods, improve teaching quality and reach a new student audience interested in online training. They have made it possible, also, to develop innovations that affect students' skills and ways of learning. For instance, the flexibility that characterizes the Internet and university intranets is allowing better adaptations to teaching practices by enabling more effective collaborative working, group work, discussion forums, wikis, and personalized lessons.

Against this background, the impact of ICTs on the academic performance of students has become the subject of numerous debates involving economists and education scientists [4-7]. The literature mainly examines why an increase in performance (in particular, higher examination marks) might be attributable to use of ICTs in higher education [8-10]. 
The economic literature tends mainly to emphasize the role played by ICT-related equipment and its use to explain differences in performance among students, but mostly ignores the issue of digital skills.

This is especially surprising since digital skills are considered to be a prerequisite for the effective use of ICTs in education [11-13]. Other requirements favoring the efficient use of ICTs include mastery of the content provided, a critical attitude to the quality of the information available to students and the adoption of safe operating procedures.

This has led education policymakers to prioritize the acquisition of digital skills (e-skills) and issue recommendations to universities to adapt teaching models to make better use of ICTs $[14,15]$. However, few studies-and especially those using French datafocus on assessing the digital skills that students should acquire to improve their exam performance or how universities could develop better-targeted ICT development strategies.

The present paper assesses the impact of ICTs on students' exam performance and takes account of how they use these technologies. It focuses, in particular, on ICT usage favored by students to acquire the skills needed to improve their academic performance and bridge the digital divide.

We examine whether improvements in student performance are the result of the use of ICT. Existing work in this direction does not include France and, also, provides mixed results for those countries studied (see [8,16,17] for the United States; [18] for Russia; [19] for Germany; [12,20] for Spain; and [21,22] for Turkey).

Our analysis is based on a survey of 1323 students enrolled in the French universities of Nice Sophia-Antipolis, Paris-Nanterre and Paris-Saclay. We argue that improvements in student performance are observed only for high levels of digital skills. If this is the case, university strategies should include the promotion of digital skills among students.

The remainder of this paper is structured as follows. Section 2 examines the factors cited in the economic literature to explain the extent to which ICTs lead to improved exam performance among students and the issues related to use of ICTs. Section 3 describes the survey sample, the variables used to test our hypotheses and presents the proposed econometric model. Section 4 discusses the findings of our analysis. Finally, Section 5 concludes.

\section{The Impact of ICT on Student Performance}

\subsection{The Effects of ICT Equipment on Student Performance}

The effects induced by ICT equipment levels on student performance have been analyzed from two main perspectives. One focuses on the effects induced by universities' investments in ICT equipment [23-30], and the other seeks to precisely identify the impact of students' personal equipment [19,31-33]. Both literature strands are discussed in more detail below.

\subsubsection{The Beneficial Effects of University ICT Equipment on the Average Performance} of Students

Several works show that universities' investments in ICT have a positive impact on student performance [23-25]. The results of these studies suggest that these investments can lead to three major and often complementary changes.

First, investment in ICTs increases the availability of generic digital resources in the university and promotes access to similar resources developed by the universities themselves. This better accessibility is likely to lead to increases in students' use of digital content for educational purposes. For example, it has been observed that the online consultation of library resources, articles and books increased significantly with the availability of intranets involving university libraries or other archives [26].

Second, increasing ICT capital in universities can improve student participation by enabling online teaching and self-learning. Online teaching allows a focus on underperforming students while offering everyone complementary lessons. This education tool has been used to facilitate the dissemination of specific courses and techniques for teaching 
medicine or learning foreign languages. Investments in ICT can contribute, also, to reducing class sizes, which is likely to have a positive impact on student performance $[27,28]$.

Third, investments in ICT could improve the quality of the training offered, by enabling the implementation of distance support courses, involving a wider range of educational resources tailored to each audience [29]. The variety of educational materials enabled by ICTs would allow students to 'perfect their learning in the forms of teamwork, better sharing of knowledge and reducing their individualistic behaviors to promote forms of collaborative human capital' [30] (p. 274).

Fourth, several recent studies indicate that universities need to adopt an open approach to data to make information more accessible and to make universities more transparent and accountable. This would allow students and teachers to access data useful for their studies/research and provide them with the tools needed to visualize and understand data, which would have a positive impact on student performance [34-36].

However, despite a significant increase in ICT investments by universities since 2000, combined with investments to increase individual facilities, this has not led to a substantial increase in student performance or a significant decrease in university failure. Sharpe [37] refers to the higher education 'productivity puzzles' and suggests that the measurement of productivity in the service sector, especially the university sector, is problematic, despite the university sector being among the first to adopt ICTs. To our knowledge, none of the literature shows that a sharp increase in ICT equipment leads to overall performance improvements in university systems that would positively affect their 'productivity'.

2.1.2. Personal Equipment as an Explanatory Factor for Performance Differentials and the Digital Divide

Other studies focus on the possession of personal equipment by students [19,31-33]. They identify a digital divide (in terms of unequal access to ICTs) and try to understand how this affects student performance. Most works seem to agree that digital inequalities amplify pre-existing social inequalities, with the result that certain populations are doubly penalized.

Individual equipment is supposed to increase access to resources for students outside school hours and allow them to review and develop their research at home. This strand of work focuses primarily on the role of individual computers [19,31], but also considers access to the Internet and broadband. However, there is concern, also, about the sharp increase in individual equipment resulting from technological evolutions which are providing continuously cheaper solutions. For example, digital tablets can perform several of the tasks accomplished by computers, provide access to the Internet and allow complete interactivity with other computer equipment, and they are available at affordable prices. This accessibility has reduced some of the digital divide. On the one hand, this is the result of the positive dynamics characterizing ICT markets and, on the other hand, it is the result of public policies. The situation is exacerbated by increased competition, which has reduced the prices of ICT-related services and materials. At the same time, public policies have enabled improvements in student facilities, especially for the most disadvantaged students, by making equipment available to lend to students and facilitating loans and reduced prices for computers and other equipment. At the same time, universities have increased their provision of ICT equipment, although some record low rates of use of computer rooms and digital boards. Nevertheless, universities are continuing to invest in high-speed connectivity systems [32,33].

The better availability of ICT equipment in universities suggests that we need to assess the impact of students' uses of these technologies on their performance.

\subsection{Students' Innovative and Collaborative Uses of ICT Improve Their Results}

Use of, rather than provision of, ICTs is now a research priority-especially in terms of the intensity of their use-to understand changes in student performance. 
Much of the literature [38-41] focuses on traditional ICTs (computers and the Internet); however, new ICTs are transforming student behaviors, especially in terms of the time allocated to studying. There are indications that the new generation of ICTs, particularly mobile Internet, is encouraging new uses of technology that are affecting student learning. This is in part because mobile Internet and new ICTs (tablets, smartphones) allow the optimization of the time available and, especially, the time that could be allocated to work, by distributing it more efficiently and flexibly. These technologies are increasing students' working hours and decreasing the time spent learning to use ICTs. These new ICTs are enabling student involvement in defining lesson content and are increasing interactivity with teachers. These technologies are generally considered to be more appropriate in the context of higher education and the involvement of students in the design of course content, whereas these forms of interactivity are weak in traditional forms of teaching. The literature proposes three arguments in this context.

First, ICT has enabled students to move from being passive consumers of knowledge and educational resources to being active participants in teaching forms. The student is able to be the 'co-producer' of the pedagogy offered. It has been observed that students who are regular users of ICT are more likely to influence the pedagogical content of proposed teaching modules. This change of status is being accompanied by greater investment by students, which is increasing their motivation to study the topics covered. The involvement of students has a positive effect on the acquisition of the skills required for exam success.

Second, the new ICTs facilitate interaction between teacher and students by enabling feedback. They facilitate students' involvement in educational experiences, which increases their interest in the topics covered. They are also enhancing horizontal interaction and networking among students outside of formal class times. All of these interactions facilitate the assimilation of knowledge and should see student success rates increase.

Third, the new generation of ICT is allowing students to be more creative, and providing opportunities such as website creation, digital content development and start-up creation [42,43]. These opportunities are having a positive influence on their success and increasing their chances of obtaining jobs based on their digital skills.

In general, it has been found [44-46] that improved student performance is dependent on their ability to use ICT interactively with teachers and with other students and in tutorials. This interactivity increases collaborative learning and the ability to work in groups.

However, intensive use of ICTs related to participation in social networks can affect student performance negatively if this participation is unrelated to their university work $[47,48]$. The study by Vigdor et al. [17] highlights the negative effects of increased Internet connection speeds and the use of laptops among students at the University of North Carolina in the US. Their main argument is that access to high-speed Internet and individual computers increases the time spent on non-productive personal learning activities (participation in video games, downloading movies and music, etc.) and decreases the amount of time devoted to educational activities and work at home. Overall, leisure time has increased and the amount of time spent studying has decreased, which has an overall negative effect on student performance.

This has resulted in some universities blocking or limiting access to social networks and certain websites. However, it is clear also that encouraging student engagement in innovative interactive and collaborative teaching requires them to acquire certain skills. It is necessary, also, for students to have a positive perception of ICT equipment and the associated educational resources. Understanding how students value the way universities develop uses of educational ICT seems to be essential for assessing their effects on exam success and the acquisition of the necessary digital skills.

\subsection{Impact of Digital Skills on Student Performance}

As already indicated, improving student performance depends on the students' ability to use ICT interactively. A set of economic studies, which try to identify and measure 
the digital skills needed to improve student performance [11,49-52], identify three levels of digital skills [51]: instrumental, informational, and strategic. Instrumental skills are the minimum skill levels required to use a computer terminal. Information skills relate to the ability to decode, sort and understand the meaning of information, prioritize it, cross-reference its sources and store it. The acquisition of these skills is more difficult; some studies show that a high proportion of the population is unable to carry out effective research on the Internet [53]. Strategic skills refer to the skills needed to use digital tools and digital content to improve social capital, work opportunities and learning opportunities. The acquisition of these skills requires the individual ability to cooperate, share and coordinate online activities.

In general, digital skills influence the intensity of ICT use, and vice versa. It is generally accepted that the effects of ICTs on student performance depend on the intensity of their use; low and sporadic use does not improve academic performance. However, intensive use for educational purposes (searching for bibliographical references, using translation software, engaging in forums and chats, etc.) stimulates involvement in their studies and results in improved skills and performance.

There is a threshold to the development of digital skills. Low-level use of ICT does not result in the exploration of sophisticated functionalities related to the applications. This type of use is related mainly to solving technical problems and requires only basic skills (level 1 digital skills). Building effective information skills takes time (level 2 digital skills), while more intensive use allows the development of the strategic skills required to achieve particular objectives, such as increased knowledge (level 3 digital skills). Intensive use also increases self-learning skills.

Some authors highlight that the forms of learning that result from the intensive use of the Internet are believed to be the origins of stronger involvement of students in their work $[5,54]$. They feel more inclined to study when assisted by educational resources available on the Internet or supported by ICTs. Thus, these technologies promote selflearning and increase student performance by reducing aversion to work.

\subsection{Strategies for Acquiring Digital Skills Limited to the Implementation of ICT-Specific Training by Universities}

The intensity of ICT use is key to improving student performance. However, the acquisition of digital skills requires ICT-specific training and appropriate education strategies. Many universities are offering specific ICT training courses which are integrated in student curricula or offered alongside them.

Several studies underline that preliminary knowledge in computer science has a positive influence on student performance. This stream of work suggests that student gender, past experience and social origins affect the acquisition of such knowledge [55,56].

Other studies $[44-46,57,58]$ show that online teaching improves student performance if supported by dialogue during tutoring, forums and online discussions. This strand of work emphasizes that learners are more motivated if these support processes are organized and are consistent with transition from a teacher-centered learning model to a studentoriented model.

This line of work underlines, also, that teaching methods must be adapted to the students' needs and profiles. It highlights that ICT training, aimed at students and teachers, allows the development of the instrumental, informational and strategic e-skills that promote student success $[50,51,59,60]$.

The results in the literature can be explained by the fact that, initially, many universities were focused on the development of instrumental skills, but now are broadening their focus to include the development of informational and strategic skills, which tend to be underdeveloped when students first enter higher education. For example, while learners often report knowing how to use the Internet, not all are able to search for information relevant to their academic work. Additionally, the use of the Internet for educational purposes can be counterproductive if not regulated $[47,48,61]$. 
To better understand these skills and behaviors, Brown and Liedholm [4] characterized the subjects tested based on their 'cognitive style', defined by: (i) their previously developed intellectual capacities; (ii) the knowledge they have acquired in the past; and (iii) their 'attitude' to university work. The authors show that there is a panel of cognitive styles that characterize students based on their learning skills. They conclude that it is necessary to offer specific training tailored to each cognitive style in order to optimize student learning.

In general, ICT investments have improved the availability of digital resources and the quality of the interactions between teachers and students or among students. ICTs are responsible for students' greater involvement in their work and self-learning, both individually and collectively. However, investment in ICTs will only be effective if accompanied by digital skill acquisition strategies. In this context, the adoption by universities of certification schemes, such as the International Computer Driver Licence (ICDL) or the European Computer Driving Licence (ECDL), which are awarded based on users' computer skills according to international or European standards, would encourage students and teachers to improve their digital literacy in terms of ICT skills, pedagogical skills and curriculum design.

\section{Research Methodology}

\subsection{Sample and Data Collection}

Survey data were collected from a four-part questionnaire. The first part asked about the student's living environment, initial education level and social background. The second part focused on the student's management of working time and social life. The third part asked the student to estimate digital skill levels in terms of familiarity with ICT applications, such as text processing, multimedia presentation, spreadsheets, databases, specialized software, image processing, web design, etc. The students were asked to rate their perceived level of ICT skills and competencies in each area on a five-point Likert scale ranging from " 1 = No competence-no experience in the skill area" to " $5=$ High level of competence-extensive experience in the skill area". The fourth part of the questionnaire asked for an assessment of the use of ICT for educational purposes.

The research team ran a pilot survey with 120 respondents to confirm the effectiveness of the questionnaire and to identify potential issues related to misunderstanding instructions and questions, and omitted variables that caused issues. Following the pilot, the questionnaire was tweaked to ensure that all the questions were clear and accurate. The questionnaire was administered face to face to 1469 students among the 2240 students enrolled in economics and management at the universities of Côte d'Azur, Paris-Nanterre and Paris-Saclay University. The response rate was $65.58 \%$. The discrepancy between the number of registered students and the number of respondents was due to ongoing absenteeism during the distribution of the questionnaires. We sought to limit the impact of absenteeism by considering only those students who attended the second semester, and also by administering the questionnaires face to face. The sample characteristics are provided in Table 1 and show that $39.2 \%$ of them attended university in the first year, $35.1 \%$ in the second year and $25.7 \%$ in the third year.

\subsection{Defining the Selected Variables \\ 3.2.1. The Dependent Variable}

According to the methodology adopted by other studies $[22,62,63]$, exam grades were used as an indicator of academic performance. The variable was constructed based on a fixed-scale scoring system (fixed grading system) which sums the student's marks for the year and transforms them into an average. We have thus established the following scale: average above, 14/20 — A (Good, Very Good and Excellent); 12/20 to 13.99/20_B (Satisfactory); 10/20 to 11.99/20-C (Passable); 8/20 to 9.99/20-D (Insufficient); less than 8/20-E-(Very insufficient). 
Table 1. Sample characteristics.

\begin{tabular}{|c|c|c|}
\hline Variable & Variables (No. 1323) & Distribution (\%) \\
\hline \multirow{2}{*}{ Gender } & Female & 48.90 \\
\hline & Male & 51.10 \\
\hline \multirow{4}{*}{ Age } & 17 to 19 years old & 38.40 \\
\hline & 20 to 21 years old & 34.62 \\
\hline & 22 to 23 years old & 20.18 \\
\hline & 24 and over & 6.80 \\
\hline \multirow{3}{*}{ University } & Paris-Saclay University & 71.96 \\
\hline & University of Paris-Nanterre & 21.47 \\
\hline & University Côte d'Azur & 6.58 \\
\hline \multirow{3}{*}{ Educational level } & L1 & 39.15 \\
\hline & $\mathrm{L} 2$ & 35.15 \\
\hline & L3 & 25.70 \\
\hline \multirow{6}{*}{ Baccalaureate series } & $\begin{array}{c}\text { Baccalaureate ES (Economics and } \\
\text { Social Sciences) }\end{array}$ & 68.41 \\
\hline & Baccalaureate S (Sciences) & 17.91 \\
\hline & Baccalaureate L (Literature) & 0.68 \\
\hline & Technological baccalaureate & 7.63 \\
\hline & Professional baccalaureate & 0.45 \\
\hline & Foreign baccalaureate & 4.91 \\
\hline \multirow{4}{*}{ Baccalaureate results } & With standard pass & 36.51 \\
\hline & With honors & 37.11 \\
\hline & With high honors & 19.35 \\
\hline & With highest honor & 7.03 \\
\hline \multirow{2}{*}{$\begin{array}{l}\text { Studying parallel to } \\
\text { employment }\end{array}$} & Not studying parallel to employment & 70.14 \\
\hline & Studying parallel to employment & 29.86 \\
\hline \multirow{2}{*}{$\begin{array}{l}\text { Hours allocated to the use of } \\
\text { ICT for educational purposes }\end{array}$} & Less than $6 \mathrm{~h}$ per week & 77.85 \\
\hline & $6 \mathrm{~h}$ and more & 22.15 \\
\hline \multirow{2}{*}{ The intensity of Internet use } & The low intensity of Internet use & 48.68 \\
\hline & High intensity of Internet use & 51.32 \\
\hline \multirow{2}{*}{$\begin{array}{l}\text { Owning a computer in } \\
\text { the home }\end{array}$} & Not owning a computer at home & 11.72 \\
\hline & Owning a computer at home & 88.28 \\
\hline \multirow{2}{*}{ Owning a laptop } & Not owning a laptop & 17.69 \\
\hline & Owning a laptop & 82.31 \\
\hline \multirow{2}{*}{$\begin{array}{l}\text { Owning an Internet } \\
\text { connection at home }\end{array}$} & Not owning an internet connection at home & 3.7 \\
\hline & Owning an internet connection at home & 96.3 \\
\hline \multirow{2}{*}{ Motivation for studies } & Low motivation for studies & 19.50 \\
\hline & Strong motivation for studies & 80.50 \\
\hline \multirow{2}{*}{$\begin{array}{l}\text { Preparing for courses } \\
\text { in advance }\end{array}$} & Not preparing for courses in advance & 49.81 \\
\hline & Preparing for courses in advance & 50.19 \\
\hline
\end{tabular}

\subsubsection{The Variables of Interest}

We considered four factors to understand the role of the variables of interest in students' academic performance (see Table 2): (i) ICT equipment; (ii) new uses induced by ICT; (iii) student level of skills required to use ICT and their perception of its utility; (vi) student's attendance at training courses to improve digital skills. 
Table 2. List of variables.

\begin{tabular}{|c|c|c|c|}
\hline Variables & Nature of the Variable & Min & $\operatorname{Max}$ \\
\hline \multicolumn{4}{|l|}{ Dependent variable } \\
\hline Overall average & Grades from A to E & $\mathrm{E}$ & A \\
\hline \multicolumn{4}{|l|}{ ICT equipment } \\
\hline Owning a laptop & Dichotomous variable & 0 & 1 \\
\hline Owning an Internet connection at home & Dichotomous variable & 0 & 1 \\
\hline University ICT equipment & The score calculated based on equipment & 2.95 & 14.76 \\
\hline \multicolumn{4}{|l|}{ ICT use } \\
\hline ICT and work flexibility & Calculated score & 1.43 & 7.16 \\
\hline Perceived usefulness of ICT use & Calculated score & 5.68 & 28.38 \\
\hline Collaborative uses of ICT & Calculated score & 2.02 & 10.10 \\
\hline Innovative uses of ICT & Calculated score & 2.75 & 13.74 \\
\hline Creative uses of ICT & Calculated score & 1.52 & 7.59 \\
\hline \multicolumn{4}{|l|}{ Digital Skills } \\
\hline Computer skills & Calculated score & 3.43 & 17.16 \\
\hline Skills for internet use & Calculated score & 2.88 & 14.39 \\
\hline ICT skills & Three levels of digital skills & 1 & 3 \\
\hline Basic ICT skills & Dichotomous variable & 0 & 1 \\
\hline Intermediate ICT skills & Dichotomous variable & 0 & 1 \\
\hline Advanced ICT skills & Dichotomous variable & 0 & 1 \\
\hline \multicolumn{4}{|l|}{ ICT training } \\
\hline ICT-related training offered by the university & Dichotomous variable & 0 & 1 \\
\hline $\begin{array}{l}\text { Training follow-up related to the use of specific ICT } \\
\text { tools }\end{array}$ & Dichotomous variable & 0 & 1 \\
\hline \multicolumn{4}{|l|}{ Control variables } \\
\hline Educational level & L1, L2, L3 & 1 & 3 \\
\hline Gender & Dichotomous variable & 0 & 1 \\
\hline Age & Four age categories are considered & 1 & 4 \\
\hline Baccalaureate honors & $\begin{array}{l}\text { Four categories of honors degree are } \\
\text { considered }\end{array}$ & 1 & 4 \\
\hline Studying parallel to employment & Dichotomous variable & 0 & 1 \\
\hline Preparing for courses in advance & Dichotomous variable & 0 & 1 \\
\hline Motivation for studies & Dichotomous variable & 0 & 1 \\
\hline
\end{tabular}

First, we consider variables for the level of access to ICT equipment in the student's home and at the university. We took account of whether or not the student had an Internet connection at home and whether or not the student owned a computer. We assessed the university ICT equipment based on questions about teaching rooms, the existence or not of technical support, the availability or not of software specific to the subjects taught and free access or not to computer rooms.

Second, we assessed a set of variables relating to the range of uses of ICTs and their effect on ability to innovate, how much use of ICTs improved the education experience and the 'perceived usefulness' of the use of ICTs.

Third, we constructed variables to characterize students' digital skills levels. We evaluated ICT skill level, uses made of ICT and perceived usefulness. To estimate ICT proficiency level and the diversity of uses of ICT, we built a 5-point Likert scale to measure self-perceptions. We employed principal component analysis (PCA) to investigate the most significant skills. The findings reveal that the saturation of items on factors is acceptable (see Table 3). According to Tabachnick and Fidel [64], only variables with correlations greater than 0.5 should be retained. We checked the internal consistency of the items forming the highlighted components using Cronbach's alpha. According to the thresholds used in Hair et al. [65] and Nunnally and Bernstein [66], Cronbach's alphas are sufficient to conclude that the eight factors identified have satisfactory internal consistency. Table 4 presents the reliability analysis of the items. 
Table 3. Rotary factorial matrix of the explanatory variables for the level of ICT skills and uses by students.

\begin{tabular}{|c|c|c|}
\hline Items & Standard Deviation & Saturation \\
\hline \multicolumn{3}{|l|}{ Factor 1: ICT equipment endowments } \\
\hline EQUIP1: Open-access computer rooms & 1.115 & 0.768 \\
\hline EQUIP2: Provision of discipline-specific software & 1.238 & 0.753 \\
\hline EQUIP3: Provision of media classrooms & 1.264 & 0.617 \\
\hline EQUIP4: Provision of technical support & 1.265 & 0.585 \\
\hline \multicolumn{3}{|l|}{ Factor 2: Computer Skills } \\
\hline SKILL1: Degree of mastery of presentation software & 0.971 & 0.811 \\
\hline SKILL2: Degree of mastery of word processing software & 0.847 & 0.796 \\
\hline SKILL3: Degree of mastery of spreadsheets & 1.008 & 0.795 \\
\hline SKILL4: Degree of mastery of discipline-specific software & 1.055 & 0.770 \\
\hline SKILL5: Degree of control over device installation & 1.062 & 0.741 \\
\hline \multicolumn{3}{|l|}{ Factor 3: Internet Skills } \\
\hline $\begin{array}{l}\text { SKILL6: Degree of proficiency in social } \\
\text { network applications }\end{array}$ & 1.291 & 0.759 \\
\hline $\begin{array}{l}\text { SKILL7: Degree of proficiency in chats and } \\
\text { forum applications }\end{array}$ & 1.266 & 0.743 \\
\hline SKILL8: Degree of proficiency in messaging software & 1.244 & 0.711 \\
\hline SKILL9: Degree of proficiency in search engine use & 1.179 & 0.699 \\
\hline $\begin{array}{c}\text { SKILL10: Degree of proficiency in online } \\
\text { teaching platforms }\end{array}$ & 1.179 & 0.667 \\
\hline \multicolumn{3}{|l|}{ Factor 4: Perceived usefulness of ICT use } \\
\hline UTIL1: The use of ICT increases interest in the course & 1.185 & 0.787 \\
\hline $\begin{array}{l}\text { UTIL2: The use of ICT improves the understanding of } \\
\text { content seen in the classroom }\end{array}$ & 1.095 & 0.757 \\
\hline UTIL3: Using ICT improves learning & 1.176 & 0.751 \\
\hline $\begin{array}{c}\text { UTIL4: ICT courses lead students to spend more time on } \\
\text { their studies }\end{array}$ & 1.221 & 0.748 \\
\hline $\begin{array}{c}\text { UTIL5: Obtain better results for lessons where teachers } \\
\text { use ICT }\end{array}$ & 1.271 & 0.713 \\
\hline $\begin{array}{l}\text { UTIL6: The use of ICT allows students to deepen the } \\
\text { content of the courses offered face to face }\end{array}$ & 1.149 & 0.697 \\
\hline $\begin{array}{c}\text { UTIL7: Tendency to recommend courses where teachers } \\
\text { use ICT }\end{array}$ & 1.290 & 0.692 \\
\hline $\begin{array}{c}\text { UTIL8: The use of ICT improves the presentation and } \\
\text { organization of work }\end{array}$ & 1.130 & 0.632 \\
\hline \multicolumn{3}{|l|}{ Factor 5: Innovative uses of ICT } \\
\hline INNOV1: Providing digital resources to other students & 1.070 & 0.747 \\
\hline INNOV2: Development of educational resources & 0.947 & 0.722 \\
\hline INNOV3: Suggesting changes to educational resources & 0.838 & 0.707 \\
\hline $\begin{array}{l}\text { INNOV4: Suggesting changes to courses offered } \\
\text { by teachers }\end{array}$ & 1.021 & 0.671 \\
\hline \multicolumn{3}{|l|}{ Factor 6: Collaborative uses of ICT } \\
\hline $\begin{array}{l}\text { COLLAB1: Using ICT makes it easier to work } \\
\text { with colleagues }\end{array}$ & 1.171 & 0.788 \\
\hline COLLAB2: Working in a group using ICT & 1.298 & 0.757 \\
\hline COLLAB3: Working on several projects using ICT & 1.292 & 0.737 \\
\hline \multicolumn{3}{|l|}{ Factor 7: Creative uses of ICT } \\
\hline CREATIV1: ICT is the source of ideas for business creation & 1.288 & 0.671 \\
\hline CREATIV2: ICT helps develop innovative ideas & 1.206 & 0.648 \\
\hline \multicolumn{3}{|l|}{ Factor 8: Work flexibility } \\
\hline FLEXIB1: Working at all times through ICT is beneficial & 1.239 & 0.845 \\
\hline FLEXIB2: Using mobile devices for study & 1.443 & 0.787 \\
\hline
\end{tabular}


Table 4. Factors retained and variance explained.

\begin{tabular}{ccccc}
\hline Factors & Own Values & \% of Variance & \% Cumulative & Cronbach Alpha \\
\hline Factor 1: University ICT Equipment & 6.554 & 19.860 & 19.860 & 0.736 \\
Factor 2: Computer Skills & 3.210 & 9.727 & 29.587 & 0.779 \\
Factor 3: Internet Skills & 2.361 & 7.154 & 36.741 & 0.699 \\
Factor 4: Perceived usefulness of ICT use & 1.971 & 5.972 & 42.713 & 0.878 \\
Factor 5: Innovative use of ICT & 1.671 & 5.065 & 47.777 & 0.788 \\
Factor 6: Collaborative use of ICT & 1.248 & 3.782 & 51.559 & 0.815 \\
Factor 7: Creative use of ICT & 1.156 & 3.503 & 55.062 & 0.803 \\
Factor 8: Work flexibility & 1.024 & 3.103 & 58.164 & 0.686 \\
\hline
\end{tabular}

To determine the relevance of the main component analysis, we conducted three tests, applied to the 33 defined items (see Table 5).

Table 5. Results of the PCA tests applied to the uses of ICT retained by the students.

\begin{tabular}{ccc}
\hline Kaiser-Meyer-Olkin Sampling Accuracy Measure (KMO) & $\mathbf{0 . 8 6 4}$ \\
\hline \multicolumn{2}{c}{ The determinant of the correlation matrix } & 0.000014 \\
\hline \multirow{3}{*}{ Bartlett's sphericity test } & Approximate chi-square & 14639.643 \\
& ddl & 528 \\
& Meaning of Bartlett & 0.000 \\
\hline
\end{tabular}

Table 5 shows that the determinant of the correlation matrix is relatively small but not zero (0.000014), which justifies the factor structure presented in Table 3. The KMO test is equal to 0.864 , indicating the strong validity of that structure. Finally, Bartlett's test indicates that the null hypothesis of all correlations being zero is rejected. Therefore, the search for components is justified.

Based on Tables 3 and 4, we retain the following variables (components) for the econometric analysis:

- $\quad$ The amount ICT equipment made available to students by universities;

- Students' computer skills;

- Students' Internet skills, i.e., level of skills to search, select and analyze large amounts of information in a meaningful way;

- The perceived usefulness of ICT-specific tools. Items positively correlated to this component reflect students' beliefs about the performance and efficiency gains resulting from use of these tools;

- Innovative educational uses resulting from ICTs and developed by the student;

- The educational benefits of using remote working tools, including collaborative work enabled by the co-presence of students via asynchronous and synchronous collaborative communication tools;

- Creative uses enabled by ICT;

- The impact of using ICT-related tools on flexible working.

To establish a typology of student abilities to use ICT, we used factor scores obtained for key components (computer skills and Internet skills) to conduct non-hierarchical $\mathrm{k}$-means clustering analysis $[67,68]$. To determine the optimal number of groups, we selected three classification criteria [68]: the minimization of the ratio of intra-group to inter-group variance (Fisher test); the number of students in each group; and the relevance economic interpretation of the identified groups. We defined three ICT usage profiles: basic, intermediate and advanced.

We also included variables for participation in ICT training in or outside the university. 


\subsubsection{Control Variables}

We considered students' personal and socio-economic characteristics, the amount of time they devote to their studies and their level of motivation. We included variables for gender, level of education, baccalaureate series, baccalaureate honors and participation in professional activities.

We asked specifically about how much time students spent preparing for their courses; the answers were coded 1 if the student prepared for courses in advance, 0 if not.

We included a question about motivation to study, which was coded 1 if the student declared being motivated and 0 for low level of motivation.

\subsection{Model Specification}

Given the issues raised, the nature of our outcome variables and the data/sampling structure, we have chosen to use a discrete choice model of the ordered logit type [62,63]. This type of model is justified as long as the dependent variable (grades attained by the students) has more than two categories (outcomes) and is ordinal in nature (Very insufficient; Insufficient; Passable; Satisfactory; Good, Very Good and Excellent). Similar studies have used ordered logit-type models using the same type of data to analyze student performance $[18,22,32,69,70]$.

The dependent variable is inherently unobservable, and its index model is written as:

$$
Y_{i}^{*}=\beta^{\prime} X_{i}+\varepsilon_{i}
$$

where $X$ denotes the vector of factors or predictors explaining the academic performance of student $i, \beta$ represents the vector of coefficient parameters to be estimated and $\varepsilon_{i}$ is the vector of normally distributed error terms.

Formally, we admit that there is a latent variable $Y^{*}$ that depends on a set of explanatory variables that determine the choice by student $i$. In addition, there are three thresholds or cut points, $\mu_{1}, \mu_{2}$ and $\mu_{3}$, which determine the observed outcome (the different grades that could be achieved by the student). Hence, the observed variable that represents the academic performance category can be expressed as in Equation (2):

$$
Y_{i}= \begin{cases}1 \text { (or grade of } \mathrm{E}) \text { if } Y_{i}^{*} \leq 0 \quad & \text { (Very insufficient) } \\ 2 \text { (or grade of D) if } 0<Y_{i}^{*} \leq \mu_{1} & \text { (Insufficient) } \\ 3 \text { (or grade of } \mathrm{C}) \text { if } \mu_{1}<Y_{i}^{*} \leq \mu_{2} & \text { (Passable) } \\ 4 \text { (or grade of } \mathrm{B}) \text { if } \mu_{2}<Y_{i}^{*} \leq \mu_{3} & \text { (Satisfactory) } \\ 5 \text { (or grade of } \mathrm{A}) \text { if } \mu_{3}<Y_{i}^{*} & \text { (Good, Very Good and Excellent) }\end{cases}
$$

The probability of the student's academic performance $Y_{i}$ to belong to the category $j$ if $\mu_{j-1}<Y_{i} \leq \mu_{j}$, where $J=\{1,2,3,4,5\}$, is given by Equation (3):

$$
P_{i}\left(Y_{i}=j\right)=\varphi\left(\mu_{j}-\beta^{\prime} X_{i}\right)-\varphi\left(\mu_{j-1}-\beta^{\prime} X_{i}\right)
$$

where,

$P_{i}\left(Y_{i}=j\right)$ is the probability that student $i$ will achieve grade $j$;

$\varphi(\cdot)$ is the cumulative standard normal distribution function;

$\mu_{j}$ and $\mu_{j-1}$ are the upper and lower threshold values for category $j$.

In other words, if $\beta^{\prime} X$ is high, the student will obtain a higher grade, while if $\beta^{\prime} X$ is low, the student will obtain a lower grade.

Additionally, it should be noted that given the non-linearity of ordered logit models, the standard interpretation of the estimated coefficients is not necessarily easy. Therefore, for ease of analysis, marginal effects were calculated for each variable. Furthermore, a multicollinearity test, homoscedasticity test, omitted variables test and normality test for residuals [62] were performed to ensure valid results for interpretation. 


\section{Results}

The model was tested in two ways. The first analyzes the probability that students will obtain a high mark if they spend less than $6 \mathrm{~h}$ per week on the Internet for educational purposes (Model 1). The second analyses this same probability for all the students in the sample (Model 2).

The econometric estimate accounts for several explanatory dimensions of students' academic achievement. We discuss the main results obtained for the four sets of explanatory factors of interest. These results are reported in Tables 6 and 7.

Table 6. Estimates of marginal effects-Model 1 f,g: Intensity of ICT use less than $6 \mathrm{~h}$ per week.

\begin{tabular}{|c|c|c|c|c|c|c|}
\hline & Coefficient & E & D & $\mathrm{C}$ & B & A \\
\hline Gender $^{a}$ & $\begin{array}{c}0.5119 * * * \\
(0.2237)\end{array}$ & $-0.005^{* * *}$ & $\begin{array}{c}-0.0469 * * * \\
(0.0131)\end{array}$ & $-0.0408^{* * *}$ & $\begin{array}{c}0.0872 * * * \\
(0.0229)\end{array}$ & $\begin{array}{c}0.0058 * * * \\
(0.0019)\end{array}$ \\
\hline $\mathrm{L} 2^{\mathrm{b}}$ & $\begin{array}{c}0.2052 \\
(0.1905)\end{array}$ & -0.002 & -0.0182 & $\begin{array}{c}-0.0178 \\
(0.0146)\end{array}$ & $\begin{array}{c}0.0357 \\
(0.0273)\end{array}$ & $\begin{array}{c}0.0024 \\
(0.0019\end{array}$ \\
\hline & $0.6006^{* * *}$ & $-0.005^{* * *}$ & $-0.0494^{* * *}$ & $-0.0623^{* * *}$ & $0.1092 * * *$ & $0.0079^{* * *}$ \\
\hline L3 & $(0.3048)$ & $(0.002)$ & $(0.0130)$ & $(0.0216)$ & $(0.0319)$ & $(0.0029)$ \\
\hline Baccalaureate S (Sciences) ${ }^{c}$ & -0.1593 & 0.002 & 0.0151 & 0.0115 & -0.0265 & -0.0017 \\
\hline & $\begin{array}{l}(0.1392) \\
-0.6961\end{array}$ & $\begin{array}{c}(0.002) \\
0.010\end{array}$ & $\begin{array}{c}(0.0161) \\
0.0810\end{array}$ & $\begin{array}{c}(0.0107) \\
0.0132\end{array}$ & $\begin{array}{l}(0.0267) \\
-0.0985\end{array}$ & $\begin{array}{l}(0.0017) \\
-0.0057\end{array}$ \\
\hline Baccalaureate L (Literature) ${ }^{c}$ & $(0.2888)$ & $(0.012)$ & $(0.0825)$ & $(0.0267)$ & $(0.0656)$ & $(0.0035)$ \\
\hline Technological baccalaureate ${ }^{c}$ & 0.0921 & -0.001 & -0.0082 & -0.0081 & 0.0160 & 0.0011 \\
\hline & $\begin{array}{l}(0.2616) \\
-1.4149 * * *\end{array}$ & $\begin{array}{c}(0.002) \\
0.031\end{array}$ & $\begin{array}{l}(0.0205) \\
0.2014 * *\end{array}$ & $\begin{array}{l}(0.0225) \\
-0.0627\end{array}$ & $\begin{array}{l}(0.0423) \\
-0.1605^{* * *}\end{array}$ & $\begin{array}{l}(0.0029) \\
-0.0087^{* * *}\end{array}$ \\
\hline Professional baccalaureate $^{c}$ & $(0.1263)$ & $(0.021)$ & $(0.0968)$ & $(0.0830)$ & $(0.0351)$ & $(0.0024)$ \\
\hline Foreign baccalaureate $^{c}$ & $\begin{array}{c}0.4674 \\
(0.5141)\end{array}$ & $\begin{array}{c}-0.004 \\
(0.002)\end{array}$ & $\begin{array}{l}-0.0361 \\
(0.0213)\end{array}$ & $\begin{array}{l}-0.0544 \\
(0.0478)\end{array}$ & $\begin{array}{c}0.0878 \\
(0.0652)\end{array}$ & $\begin{array}{c}0.0066 \\
(0.0058)\end{array}$ \\
\hline & 0.1769 & -0.002 & -0.0158 & -0.0150 & 0.0306 & 0.0021 \\
\hline With honors ${ }^{\mathrm{d}}$ & $(0.1678)$ & $(0.001)$ & $(0.0125)$ & $(0.0126)$ & $(0.0245)$ & $(0.0018)$ \\
\hline With high honors ${ }^{d}$ & $0.6714^{* * *}$ & $-0.006^{* * *}$ & $-0.0526^{* * *}$ & $-0.0763^{* * *}$ & $0.1251^{* * *}$ & $0.0094^{* * *}$ \\
\hline & $0.7626^{* * *}$ & $-0.006^{* * *}$ & $-0.0546^{* * *}$ & $-0.0998^{* *}$ & $\begin{array}{l}(0.0366) \\
0.1481^{* * *}\end{array}$ & $0.0121^{(0.0037)}$ \\
\hline With highest honor ${ }^{\mathrm{a}}$ & $(0.5879)$ & $(0.002)$ & $(0.0156)$ & $(0.0480)$ & $(0.0578)$ & $(0.0065)$ \\
\hline Studying parallel to employment & $\begin{array}{c}-1.3727^{* * *} \\
(0.0360)\end{array}$ & $\begin{array}{c}0.019^{* * *} \\
(0.005)\end{array}$ & $\begin{array}{c}0.1486^{* * *} \\
(0.0217)\end{array}$ & $\begin{array}{c}0.0544^{* * *} \\
(0.0173)\end{array}$ & $\begin{array}{c}-0.2081^{* * *} \\
(0.0216)\end{array}$ & $\begin{array}{c}-0.0135^{* * *} \\
(0.0033)\end{array}$ \\
\hline Motivation & $0.9344^{* * *}$ & $-0.012^{* * *}$ & $-0.1019^{* * *}$ & $-0.0346^{* * *}$ & $0.1403^{* * *}$ & $0.0086^{* * *}$ \\
\hline IVIOLIVALIOH & $(0.3931)$ & $(0.004)$ & $(0.0210)$ & $(0.0122)$ & $(0.0216)$ & $(0.0022)$ \\
\hline Preparing for courses in advance & $0.3223 * *$ & $-0.003^{* *}$ & $-0.0290^{* *}$ & $-0.0270^{* *}$ & $0.0555 * *$ & $0.0037 * *$ \\
\hline & $(0.1899)$ & $(0.001)$ & $(0.0126)$ & $(0.0123)$ & $(0.0238)$ & $(0.0018)$ \\
\hline Owning a computer at home & $\begin{array}{l}-0.1001 \\
(01822)\end{array}$ & 0.001 & 0.0089 & 0.0088 & -0.0174 & -0.0012 \\
\hline & $\begin{array}{l}(0.1822) \\
-0.4456\end{array}$ & $(0.002)$ & $(0.0173)$ & $(0.0190)$ & $(0.0357)$ & $(0.0025)$ \\
\hline Owning an Internet connection at home & $(0.2616)$ & $(0.003)$ & $(0.0271)$ & $(0.0599)$ & $(0.0825)$ & $(0.0070)$ \\
\hline & 0.2756 & -0.003 & -0.0268 & -0.0181 & 0.0451 & 0.0029 \\
\hline Owning a laptop & $(0.2354)$ & $(0.002)$ & $(0.0187)$ & $(0.0093)$ & $(0.0278)$ & $(0.0018)$ \\
\hline & 0.1033 & -0.001 & -0.0095 & -0.0081 & 0.0175 & 0.0011 \\
\hline ICT-related training offered by universities & $(0.1502)$ & $(0.001)$ & $(0.0127)$ & $(0.0102)$ & $(0.0227)$ & $(0.0015)$ \\
\hline Following training related to the use of ICT tools & $\begin{array}{c}0.6249 * * * \\
(0.2700)\end{array}$ & $\begin{array}{l}-0.006 \\
(0.002)\end{array}$ & $\begin{array}{c}-0.0528 \\
(0.0117)\end{array}$ & $\begin{array}{c}-0.0613^{* * *} \\
(0.0188)\end{array}$ & $\begin{array}{c}0.1119 * * * \\
(0.0276)\end{array}$ & $\begin{array}{c}0.0080^{* * *} \\
(0.0026)\end{array}$ \\
\hline ICT equipment at university & 0.0395 & -0.001 & -0.0036 & -0.0032 & 0.0068 & 0.0004 \\
\hline & $(0.0302)$ & $(0.001)$ & $(0.0026)$ & $(0.0024)$ & $(0.0049)$ & $(0.0003)$ \\
\hline Perceived usefulness of ICT use & $\begin{array}{l}0.2339^{* * *} \\
(0.0271)\end{array}$ & $\begin{array}{c}-0.002^{* * *} \\
(0.001)\end{array}$ & $\begin{array}{c}-0.0213^{* * * *} \\
(0.0023)\end{array}$ & $\begin{array}{l}-0.0189 * * * \\
(0.0036)\end{array}$ & $\begin{array}{c}0.0400 * * * \\
(0.0039)\end{array}$ & $\begin{array}{l}0.0026^{* * *} \\
(0.0005)\end{array}$ \\
\hline Intermediate ICT skills $\mathrm{e}$ & $1.1167^{* * *}$ & $-0.012^{* * *}$ & $-0.1008^{* * *}$ & $-0.0936^{* * *}$ & $0.1922 * * *$ & $0.0137^{* * *}$ \\
\hline & $\begin{array}{c}(0.4708) \\
2.6444^{* * *}\end{array}$ & $\begin{array}{c}(0.002) \\
-0.016 * * *\end{array}$ & $\begin{array}{c}(0.0150) \\
-0.1460^{* * *}\end{array}$ & $\begin{array}{c}(0.0184) \\
-0.4063 * * *\end{array}$ & $\begin{array}{c}(0.0262) \\
0.4857 * * *\end{array}$ & $\begin{array}{l}(0.0030) \\
0.0823 * * *\end{array}$ \\
\hline Advanced ICT skills ${ }^{\mathrm{e}}$ & $(3.6531)$ & $\begin{array}{l}-0.010 \\
(0.003)\end{array}$ & $(0.0130)$ & $(0.0471)$ & $(0.0410)$ & $(0.0161)$ \\
\hline ICT and work flexibility & $\begin{array}{c}0.2287^{* * *} \\
(0.0600)\end{array}$ & $\begin{array}{c}-0.002^{* * *} \\
(0.001)\end{array}$ & $\begin{array}{c}-0.0208^{* * *} \\
(0.0044)\end{array}$ & $\begin{array}{c}-0.0185^{* * *} \\
(0.0050)\end{array}$ & $\begin{array}{c}0.0391^{* * *} \\
(0.0083)\end{array}$ & $\begin{array}{c}0.0026^{* * *} \\
(0.0007)\end{array}$ \\
\hline Collahorative 1 se of ICT & $0.4238^{* * *}$ & $-0.004^{* * *}$ & $-0.0386^{* * *}$ & $-0.0343^{* * *}$ & $0.0724^{* * *}$ & $0.0048^{* * *}$ \\
\hline Collaborative use of ICl & $(0.0656)$ & $(0.001)$ & $(0.0045)$ & $(0.0065)$ & $(0.0077)$ & $(0.0010)$ \\
\hline Innovative use of ICT & $0.2889 * * *$ & $-0.003^{* * *}$ & $-0.0263^{* * *}$ & $-0.0234^{* * *}$ & $0.0494^{* * *}$ & $0.0033^{* * *}$ \\
\hline & $(0.0582)$ & $(0.001)_{* * *}$ & $(0.0040)$ & $(0.0054)$ & $(0.0079)$ & $(0.0007)$ \\
\hline Creative use of ICT & $\begin{array}{l}0.1765^{* * *} \\
(0.0517)\end{array}$ & $\begin{array}{c}-0.002^{* * *} \\
(0.001)\end{array}$ & $\begin{array}{c}-0.0161^{* * *} \\
(0.0041)\end{array}$ & $\begin{array}{c}-0.0143^{* * *} \\
(0.0041)\end{array}$ & $\begin{array}{l}0.0302 * * * \\
(0.0074)\end{array}$ & $\begin{array}{l}0.0020^{* * *} \\
(0.0006)\end{array}$ \\
\hline Pseudolikelihood Log & \multicolumn{6}{|c|}{-912.17739} \\
\hline Pseudo $\mathrm{R}^{2}$ & \multicolumn{6}{|c|}{$36.97 \%$} \\
\hline Wald $\operatorname{chi}^{2}(27)$ & \multicolumn{6}{|c|}{474.08} \\
\hline Observations & \multicolumn{6}{|c|}{982} \\
\hline
\end{tabular}

Notes: ${ }^{a-e}$ : Reference variables, as follows. ${ }^{a}$ : Gender (woman). b: Level of education ("License 1" (L1)) ${ }^{c}$ : Baccalaureate series (Economics and Social Sciences (ES)). ${ }^{\mathrm{d}}$ : Baccalaureate honors (with standard pass). e : Level

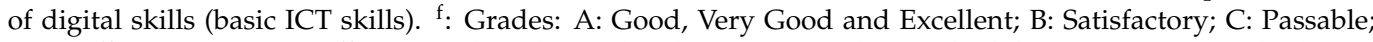
D: Insufficient; E: Very insufficient. ${ }^{\mathrm{g}}$ : the values in brackets represent the standard deviations. ${ }^{* * *},{ }^{* *}$ and ${ }^{*}$ denote statistical significance level at $1 \%, 5 \%$ and $10 \%$, respectively. 
Table 7. Estimates of marginal effects-Model $2{ }^{\mathrm{f}, \mathrm{g}}$ : Global.

\begin{tabular}{|c|c|c|c|c|c|c|}
\hline & Coefficient & $\mathbf{E}$ & $\mathbf{D}$ & $\mathrm{C}$ & B & A \\
\hline Gender $^{\mathrm{a}}$ & $\begin{array}{c}0.4303^{* * *} \\
(0.1708)\end{array}$ & $\begin{array}{c}-0.0030 \\
(0.0010)\end{array}$ & $\begin{array}{c}-0.0253^{* * *} \\
(0.0071)\end{array}$ & $\begin{array}{c}-0.0740^{* * *} \\
(0.0192)\end{array}$ & $\begin{array}{c}0.0881^{* * *} \\
(0.0229)\end{array}$ & $\begin{array}{c}0.0142 \text { *** } \\
(0.0039)\end{array}$ \\
\hline & 0.1224 & -0.0008 & -0.0070 & -0.0215 & 0.0252 & 0.0041 \\
\hline $\mathrm{L} 2^{\mathrm{b}}$ & $(0.1472)$ & $(0.0009)$ & $(0.0073)$ & $(0.0232)$ & $(0.0270)$ & $(0.0044)$ \\
\hline $\mathrm{ab}$ & $0.5543^{* * *}$ & $-0.0034^{* * *}$ & $-0.0290^{* * *}$ & $-0.1024^{* * *}$ & $0.1139^{* * *}$ & $0.0208^{* * *}$ \\
\hline $\mathrm{L}^{\mathrm{O}}$ & $(0.2498)$ & $(0.0010)$ & $(0.0073)$ & $(0.0281)$ & $(0.0296)$ & $(0.0063)$ \\
\hline Baccalaureate S (Sciences) ${ }^{c}$ & $-0.2931^{* *}$ & $0.0022 * *$ & $0.0185 * *$ & $0.0476 * *$ & $-0.0595^{* * *}$ & $-0.0088^{* *}$ \\
\hline & $\begin{array}{c}(0.1026) \\
-09610 * * *\end{array}$ & $(0.0012)$ & $(0.0096)$ & $(0.0210)$ & $\begin{array}{l}(0.0275) \\
-01744 * * *\end{array}$ & $\begin{array}{l}(0.0041) \\
-00209^{* * *}\end{array}$ \\
\hline Baccalaureate L (Literature) $^{c}$ & $(0.1866)$ & $(0.0087)$ & $\begin{array}{c}0.0831 \\
(0.0582)\end{array}$ & $(0.0166)$ & $(0.0723)$ & $(0.0072)$ \\
\hline Technological baccalaureate ${ }^{c}$ & $\begin{array}{c}0.0122 \\
(0.2183)\end{array}$ & $\begin{array}{l}-0.0001 \\
(0.0015)\end{array}$ & $\begin{array}{l}-0.0007 \\
(0.0125)\end{array}$ & $\begin{array}{l}-0.0021 \\
(0.0377)\end{array}$ & $\begin{array}{c}0.0025 \\
(0.0445)\end{array}$ & $\begin{array}{c}0.0004 \\
(0.0072)\end{array}$ \\
\hline Professional baccalaureate ${ }^{c}$ & $-0.9769 * * *$ & 0.0112 & 0.0852 & $0.1013^{* * *}$ & $-0.1766^{* * *}$ & $-0.0210 * * *$ \\
\hline & 0.0540 & -0.0004 & -0.0031 & -0.0095 & 0.0111 & 0.0018 \\
\hline Foreign baccalaureate & $(0.2750)$ & $(0.0017)$ & $(0.0146)$ & $(0.0465)$ & $(0.0539)$ & $(0.0090)$ \\
\hline With honors ${ }^{d}$ & $\begin{array}{l}0.2592^{* *} \\
(0.1530)\end{array}$ & $\begin{array}{c}-0.0017^{* *} \\
(0.0008)\end{array}$ & $\begin{array}{l}-0.0147^{* *} \\
(0.0067)\end{array}$ & $\begin{array}{l}-0.0458^{* *} \\
(0.0212)\end{array}$ & $\begin{array}{l}0.0534^{* *} \\
(0.0244)\end{array}$ & $\begin{array}{l}0.0088^{* *} \\
(0.0043)\end{array}$ \\
\hline With high honors ${ }^{d}$ & $\begin{array}{c}0.5260 * * * \\
(0.2658)\end{array}$ & $\begin{array}{c}-0.0031^{* * *} \\
(0.0009)\end{array}$ & $\begin{array}{c}-0.0269^{* * *} \\
(0.0073)\end{array}$ & $\begin{array}{c}-0.0984^{* * *} \\
(0.0316)\end{array}$ & $\begin{array}{c}0.1082^{* * *} \\
(0.0321)\end{array}$ & $\begin{array}{c}0.0202^{* * *} \\
(0.0074)\end{array}$ \\
\hline & $0.8296^{* * *}$ & $-0.0041^{* * *}$ & $-0.0362 * * *$ & $-0.1639^{* * *}$ & $0.1656^{* * *}$ & $0.0386^{* * *}$ \\
\hline With highest honor ${ }^{a}$ & $(0.5496)$ & $(0.0011)$ & $(0.0084)$ & $(0.0502)$ & $(0.0433)$ & $(0.0160)$ \\
\hline Studying parallel to employment & $\begin{array}{c}-1.2864^{* * *} \\
(0.0347)\end{array}$ & $\begin{array}{c}0.0122^{* * *} \\
(0.0030)\end{array}$ & $\begin{array}{c}0.0956^{* * *} \\
(0.0154)\end{array}$ & $\begin{array}{c}0.1719^{* * *} \\
(0.0158)\end{array}$ & $\begin{array}{c}-0.2446^{* * *} \\
(0.0214)\end{array}$ & $\begin{array}{c}-0.0351^{* * *} \\
(0.0060)\end{array}$ \\
\hline Motivation & $0.9088^{* * *}$ & $-0.0085^{* * *}$ & $-0.0676^{* * *}$ & $-0.1226^{* * *}$ & $0.1750^{* * *}$ & $0.0237 * * *$ \\
\hline Motivation & $(0.3400)$ & $(0.0023)$ & $(0.0138)$ & $(0.0161)$ & $(0.0247)$ & $(0.0043)$ \\
\hline Preparing for courses in advance & $0.4208^{* * *}$ & $-0.0029^{* * *}$ & $-0.0246^{* * *}$ & $-0.0726^{* * *}$ & $0.0862^{* * *}$ & $0.0139 * * *$ \\
\hline Preparing ror courses in aavance & $(0.1800)$ & $(0.0010)$ & $(0.0075)$ & $(0.0203)$ & $(0.0241)$ & $(0.0044)$ \\
\hline Owning a computer at home & -0.1789 & 0.0012 & 0.0098 & 0.0322 & -0.0370 & -0.0063 \\
\hline & $(0.1571)$ & $(0.0012)$ & $(0.0098)$ & $(0.0351)$ & $(0.0389)$ & $(0.0071)$ \\
\hline Owning an Internet connection at home & $\begin{array}{l}-0.14 / 3 \\
(0.3022)\end{array}$ & $(0.0021)$ & $(0.0182)$ & $\begin{array}{l}0.0266 \\
(0.0655)\end{array}$ & $\begin{array}{l}-0.0305 \\
(0.0727)\end{array}$ & $\begin{array}{l}-0.0052 \\
(0.0131)\end{array}$ \\
\hline Owning a lanton & 0.1816 & -0.0013 & -0.0111 & -0.0303 & 0.0371 & 0.0057 \\
\hline Wwing a laptop & $(0.1812)$ & $(0.0012)$ & $(0.0099)$ & $(0.0241)$ & $(0.0306)$ & $(0.0045)$ \\
\hline ICT-related training offered by universities & 0.0872 & -0.0006 & -0.0052 & -0.0150 & 0.0179 & 0.0028 \\
\hline 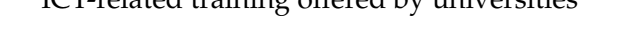 & $(0.1239)$ & $(0.0008)$ & $(0.0068)$ & $(0.0194)$ & $(0.0233)$ & $(0.0036)$ \\
\hline Following training related to the use of ICT tools & $0.6350 * * *$ & $-0.0042^{* * *}$ & $-0.0357^{* * *}$ & $-0.1121^{* * *}$ & $0.1299 * * *$ & $0.0222 * * *$ \\
\hline & $\begin{array}{c}(0.2299) \\
0.0268\end{array}$ & -0.0002 & -0.0016 & $\begin{array}{l}(0.0228) \\
-0.0046\end{array}$ & $\begin{array}{c}(0.0252) \\
0.0055\end{array}$ & $\begin{array}{c}(0.0052) \\
0.0009 * * *\end{array}$ \\
\hline ICT equipment at university & $(0.0254)$ & $(0.0002)$ & $(0.0014)$ & $(0.0044)$ & $(0.0051)$ & $(0.0008)$ \\
\hline Perceived usefulness of ICT use & $\begin{array}{c}0.2136^{* * *} \\
(0.0225)\end{array}$ & $-0.0015^{* * *}$ & $-0.0125^{* * *}$ & $-0.0371^{* * *}$ & $\begin{array}{c}0.0440^{* * *} \\
(0.0044)\end{array}$ & $0.0070^{* * *}$ \\
\hline & $0.9738^{* * *}$ & $-0.0066^{* * *}$ & $-0.0555^{* * *}$ & $-0.1687^{* * *}$ & $0.1962 * * *$ & $0.0347^{* * *}$ \\
\hline Intermediate ICT skills ${ }^{\mathrm{I}}$ & $(0.3528)$ & $(0.0013)$ & $(0.0084)$ & $(0.0247)$ & $(0.0274)$ & $(0.0055)$ \\
\hline Advanced ICT skills e & $2.4226^{* * *}$ & $-0.0113^{* * *}$ & $-0.0966^{* * *}$ & $-0.4298^{* * *}$ & $0.3766^{* * *}$ & $0.1610^{* * *}$ \\
\hline & $0.2326^{* * *}$ & $-0.0016^{* * *}$ & $-0.0136 * * *$ & $\begin{array}{l}(0.0368) \\
-0.0404^{* * *}\end{array}$ & $0.0479 * * *$ & $0.0076^{* * *}$ \\
\hline ICT and work flexibility & $(0.0505)$ & $(0.0004)$ & $(0.0024)$ & $(0.0076)$ & $(0.0086)$ & $(0.0015)$ \\
\hline Collaborative use of ICT & $0.3798^{* * *}$ & $-0.0026^{* * *}$ & $-0.0221^{* * *}$ & $-0.0659^{* * *}$ & $0.0782^{* * *}$ & $0.0125^{* * *}$ \\
\hline & $(0.0509)$ & $(0.0005)$ & $(0.0025)$ & $(0.0076)$ & $(0.0081)$ & $(0.0016)$ \\
\hline Innovative use of ICT & $0.2635 * * *$ & $-0.0018^{* * *}$ & $-0.0154^{* * *}$ & $-0.0457^{* * *}$ & $0.0542^{* * *}$ & $0.0087^{* * *}$ \\
\hline & $(0.0440)$ & $(0.0004)_{* * *}$ & $(0.0021)$ & $(0.0069)_{* * *}$ & $(0.0075)$ & $(0.0013)$ \\
\hline Creative use of ICT & $\begin{array}{l}0.1663 * * * \\
(0.0431)\end{array}$ & $\begin{array}{c}-0.0011 \\
(0.0003)\end{array}$ & $\begin{array}{l}-0.0097 * * * \\
(0.0022)\end{array}$ & $\begin{array}{l}-0.0289 * * * \\
(0.0066)\end{array}$ & $\begin{array}{l}0.0342^{* * *} \\
(0.0077)\end{array}$ & $\begin{array}{c}0.0055 \\
(0.0013)\end{array}$ \\
\hline Pseudolikelihood Log & \multicolumn{6}{|c|}{-1260.4086} \\
\hline Pseudo $\mathrm{R}^{2}$ & \multicolumn{6}{|c|}{$36.20 \%$} \\
\hline Wald chi $^{2}(27)$ & \multicolumn{6}{|c|}{626.06} \\
\hline Observations & \multicolumn{6}{|c|}{1323} \\
\hline
\end{tabular}

Notes: a-e: Reference variables, as follows. a : Gender (woman). b: Level of education ("License 1" (L1)). ${ }^{c}$ : Baccalaureate series (Economics and Social Sciences (ES)). ${ }^{\mathrm{d}}$ : Baccalaureate honors (with standard pass). ${ }^{\mathrm{e}}$ : Level

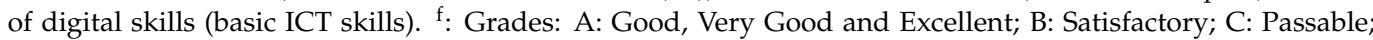
D: Insufficient; E: Very insufficient. ${ }^{g}$ : the values in brackets represent the standard deviations. ${ }^{* *},{ }^{* *}$ and ${ }^{*}$ denote statistical significance level at $1 \%, 5 \%$ and $10 \%$, respectively.

\subsection{ICT Investments Have a Small Impact on Students' Academic Success}

The econometric results for university equipment and student's personal equipment show that neither has any impact on the student's academic performance. Having a desktop computer, a laptop and an Internet connection at home does not increase the probability of a high grade and, therefore, exam success. We note that the coefficients of the last three variables are not statistically significant.

Similarly, the coefficient of the variable for university equipment is not statistically significant, suggesting that it does not affect the probability of obtaining a high grade. This 
result is in line with the argument that the generalization of ICT equipment does not mean that the performance gap among students is the result of a lack of provision of equipment. Our results show that greater provision of computer equipment does not reduce the digital divide among students.

In the current context, characterized by a substantial increase in individual equipment, the duplication of investment in ICT would not seem to be desirable. Much of the equipment purchased by universities is under-used or was decommissioned before any use was made of it. For example, the use of interactive whiteboards is extremely low in French universities despite the huge provision of whiteboards.

\subsection{Innovative and Collaborative Uses of ICT Improve Students' Results}

The econometric results obtained also confirm the analytical arguments raised concerning the student-specific uses of ICT. Indeed, the collaborative, innovative and creative uses that result from the use of ICT are statistically significant at the $1 \%$ threshold. They positively influence the probability that students will be awarded high degrees. Confirming this result, marginal effects indicate that if collaborative ICT uses increase by one unit, then the probability of a student being in the category of respondents who obtain grade $B$ increases by $7.24 \%$. On the other hand, the probability is the same when all respondents are considered $(7.82 \%)$. Similarly, the probability of a student being in the category of respondents who obtain grade A increases by $0.4 \%$ and $1.25 \%$, respectively, for both samples. Similarly, the results for marginal effects indicate that if the innovative uses of ICT increase by one unit, then the probability of a student being in the category of respondents who obtain grade B increases by $4.94 \%$. The probability is the same when all respondents are taken into consideration (5.42\%). Finally, the probability of a student belonging to the group of those who obtain grade $\mathrm{A}$ increases by $0.3 \%$ and $0.8 \%$, respectively, for both samples.

These results confirm the findings of Ben Youssef et al. [11] and Kuo et al. [71]. However, they need to be put into perspective with regard to their implications in terms of how universities manage teaching and develop education support policies. Investment in ICTs requires the simultaneous increased supervision of their use by students to ensure that it is appropriate and will not lead to weaker exam performance.

Teachers are mainly responsible for the level of adoption, use and integration of ICT in the teaching-learning process. They should provide guidance regarding the use of ICT appropriate for the particular study course. Therefore, the level of the teacher's ICT competences and the adoption, use and integration of ICT are likely to determine the students' acquisition and use of digital skills. According to Rubach and Lazarides [72], teachers' digital skills and skill beliefs are necessary conditions for the successful integration of digital technology in teaching and learning settings and students' acquisition of digital skills. Furthermore, universities and/or teachers should interact with students and not limit their interventions only to the provision of online educational resources. There is a need for methodologies related to the creative and collaborative use of appropriate ICTs to complement traditional teaching. For instance, students should be encouraged to explore the university's online resources, and teachers should make recommendations about specific sites and resources that complement their course of study. The aim should be to indicate which specific sites to consult; many students are unaware of the range of sites that could help them and, also, may not know how to use them.

At the same time, teaching should be designed to exploit the complementarity between traditional teaching methods and methods that use ICTs.

Universities and teachers should also be aware of the negative effects of the unsupervised use of ICTs in terms of reducing or, at least, not improving student performance. Student performance tends to improve if the university adopts complementary and innovative teaching methods which incorporate the use of ICTs.

Krasilnikov and Serenova [18] showed that among a population of Russian students, the intensity of ICT use for educational purposes varies across the academic year. It tends to increase around exam periods and can improve student outcomes. At other times, use 
decreases, but also tends to be non-productive, that is, not study related. This suggests that students should be taught more about the utility of certain websites in order to increase the educational uses of ICT outside of exam periods.

Our results imply that the potential of ICT to encourage collaboration and innovative uses should be further explored to reduce failure rates among, especially, first-year students. Collaborative learning could achieve better assimilation of course content. These recommendations are in line with those proposed by Kuo et al. [71]. Finally, it would be in the interests of the universities to redesign their educational strategies and promote teaching methods that combine online and offline content, forms and materials [73].

\subsection{Impact of Digital Skill Levels on Student Performance}

The two configurations of the proposed model show that there is a positive and significant (at 1\%) effect on student performance of higher levels of digital skills. The marginal effects indicate that if advanced ICT skills increase by one unit, the probability that the student will achieve a grade B increases by $48.57 \%$. This falls to $37.66 \%$ for the group that spends less than six hours a week using the Internet for educational purposes and for all respondents. These probabilities increase to $8.23 \%$ and $16.1 \%$, respectively, for both samples in relation to the achievement of an A grade.

These findings are relevant because they confirm the findings in $[18,74,75]$ and, also, because, in our case, they explain the increased probability that the student will achieve a high grade. They show, also, that students who devote fewer hours to ICT-related educational activities achieve relatively poorer academic results compared to those who use these tools more intensively.

However, these results should be interpreted with some caution. Although the length of time the student is connected to the Internet can be considered to be an indication of the students' ability to use ICTs, a longer experience of using the Internet for reasons other than educational purposes could result in shorter connection times due to accumulated experience in conducting searches, for instance. This suggests that students should be taught strategies to improve their digital skills.

It is interesting that although the survey was conducted before the onset of the COVID 19 pandemic, the results remain valid. The pandemic imposed a historically unprecedented shock on work and education systems and has disrupted all stakeholders by revealing what had been an ongoing digital skills crisis, while also opening up new opportunities. The situation promoted by the pandemic has been more difficult for teachers and students who have weak digital skills and has highlighted the lack of appropriate and accessible training programs. Many teachers and students, including those in contexts with adequate infrastructure, lack digital skills, which is a barrier not only to their ongoing professional development, but also to the teaching offer. The pandemic has revealed the effects of digital skills on the performance of workers, teachers and especially students, who are future workers.

\subsection{ICT-Specific Training Does Not Improve Student Performance}

The models studied provide counter-intuitive results. The variable 'training in use of ICT-specific tools' is not statistically significant, which suggests that the training offered by universities is insufficient.

It might be that the training offered to students is not appropriate for their needs. This might be due to the institutional rigidities that characterize French universities or, and perhaps more so, French universities' weak capacity to quickly adapt teaching models outside periods of accreditation or without the help of ICT specialists. Thus, as discussed earlier, universities need to offer specialized ICT training and to invest in certification schemes, such as the ECDL or ICDL, for teachers and students.

Learning how to use ICTs seems to depend more on informal student interactions than any well-defined university policies. Many students learn from collaboration with the most competent and skilled students, that is, through informal behavior, and not 
specific university courses. This points to a failure on the part of the universities. More resources should be devoted to training students in the use of ICTs as opposed to providing equipment which often is underutilized.

The variable 'participating in training in the use of ICT-specific tools' outside the university has a positive and statistically significant impact on students' academic performance. The marginal effect of this variable is significant in both of the proposed models. Engaging in ICT-related training increases the probability of achieving a grade B by $11.19 \%$ and $12.99 \%$, respectively, for the two model configurations selected. For the probability of obtaining a grade $\mathrm{A}$, this variable increases by $0.8 \%$ and $2.22 \%$ for the respective model configurations. Additionally, it reduces the probability of obtaining grade D by $5.28 \%$ and $3.57 \%$ and the probability of obtaining a grade $\mathrm{E}$ by $0.6 \%$ and $4.2 \%$, respectively.

The results obtained show, also, that the control variables have the expected effects. Students' motivation for their studies and the fact that they prepare for their courses positively influence their likelihood of obtaining a high grade. Working at a job while following a study course reduces this probability. In this regard, the results of the marginal effects reveal that if the 'motivation for studies' and 'preparation for courses in advance' increase by one unit, the probability that a student will achieve a B grade increases by $14.03 \%$ and $5.55 \%$ and by $17.5 \%$ and $8.62 \%$, respectively. The probability of obtaining a grade $\mathrm{A}$ increases by $0.86 \%$ and $0.37 \%$ and $2.37 \%$ and $1.39 \%$, respectively, for the sample of students who spend less than six hours per week using the Internet for educational purposes and for the total population of respondents. Working in parallel with studying at a university reduces the probability that the student will achieve a grade B by $20.81 \%$ and $24.46 \%$ and reduces the possibility of a grade A by $0.86 \%$ and $3.51 \%$ for the two models considered.

\section{Conclusions}

Digital technologies offer a range of possibilities and means to support education transformation, which requires a holistic view of technology-based education, the changes needed and an understanding of its effects. This study assessed the most relevant determinants proposed in the literature related to the impact of ICT on student performance. Our data allowed an assessment of a range of effects of ICT use on student performance. Our large sample allows us to conclude that the use of ICT can improve students' academic performance and confirm the findings provided in other studies $[18,22,69,70]$.

This study is novel in that it highlights that ICT-supported activities, such as collaboration among learners and interactive learning, have a positive influence on student success. We showed that a high level of digital skills has a positive influence on student performance and the probability of achieving a high grade. Thus, the work/leisure balance enabled by ICTs and mobile Internet is improving students' exam success significantly. This effect is due, in particular, to the possibility for teachers to offer timely help.

The proposed model also draws attention to student interactions made possible by online forums, communities of practice, interactive platforms, knowledge sharing and online help. All of these practices can be interpreted as support that has positive external effects which enhance learning.

Furthermore, we showed that if teaching material is digitized and made available to students, asynchronous forms of learning facilitate the adaptation of work rhythms compared to the rhythm of traditional teaching. Asynchronous learning would allow students to organize their time and to be more available for academic work, which, in part, might explain their better exam performance. We highlighted, also, that using ICTs, which are considered to be educational innovations, can promote certain forms of learning that result in the better assimilation of taught content.

Our findings suggest three main recommendations.

First, the need for deep organizational change in universities. The digitization of education is challenging and involves much more than just the provision of ICT equipment. 
It also requires changes to teaching tools and the implementation of new organizational practices driven by use of new digital technologies.

Second, achieving digital transformation while improving student success is a challenge for any university. Several factors must be considered to achieve this transition, including higher education teachers' knowledge, qualifications and attitudes toward technology; institutional, organizational and administrative factors; and the adequate equipment of teachers and students. However, the lack of appropriate digital skills is, among the other factors mentioned above, the main driver of the digital divide and requires the implementation of appropriate training.

Third, age is a major variable; in the context of technology, there are gaps in digital abilities between the so-called baby boomers, Gen X, millennials and Gen Z. Bridging these gaps will require different types of training and ICT-upskilling programs.

Our study has some limitations. For example, we do not consider the role of higher education governance and incentive policies to increase the use of ICT especially for incremental and generic innovations. Additionally, current assessments of teachers' and students' performance take little account of new uses of ICT, or the opportunities offered by emerging technologies such as AI, the Internet of Things, the cloud and open government data. An analysis of data from a survey on the use of ICT by students and teachers, as well as by different countries and institutions, would help to better assess the dynamics.

\begin{abstract}
Author Contributions: Conceptualization, A.B.Y. and M.D.; methodology, A.B.Y., M.D. and L.R.; formal analysis, A.B.Y., M.D. and L.R.; writing-original draft preparation, A.B.Y., M.D. and L.R.; writing - review and editing, A.B.Y., M.D. and L.R. All authors have read and agreed to the published version of the manuscript.
\end{abstract}

Funding: This research received no external funding.

Institutional Review Board Statement: Not applicable.

Informed Consent Statement: Not applicable.

Data Availability Statement: The data that support the findings of this study are available from the corresponding author upon reasonable request.

Conflicts of Interest: The authors declare no conflict of interest.

\title{
References
}

1. Ben Youssef, A.; Rallet, A. Usage des T.I.C. dans l'enseignement supérieur. Réseaux 2009, 27, 9-20. [CrossRef]

2. Henderson, M.; Selwyn, N.; Aston, R. What works and why? Student perceptions of 'useful' digital technology in university teaching and learning. Stud. High. Educ. 2017, 42, 1567-1579. [CrossRef]

3. Rodríguez-Abitia, G.; Bribiesca-Correa, G. Assessing Digital Transformation in Universities. Future Internet 2021, 13, 52. [CrossRef]

4. Brown, B.W.; Liedholm, C.E. Can web courses replace the classroom in principles of microeconomics? Am. Econ. Rev. 2002, 92, 444-448. [CrossRef]

5. Dahmani, M.; Ragni, L. L'impact des technologies de l'information et de la communication sur les performances des étudiants. Réseaux 2009, 27, 81-110. [CrossRef]

6. Mondal, S.; Culp, D. Academic performance in online versus blended classes in principles of economics and statistics courses. J. Appl. Bus. Econ. 2017, 19, 117-135.

7. Ramirez, G.M.; Collazos, C.A.; Moreira, F. All-Learning: The state of the art of the models and the methodologies educational with ICT. Telemat. Inform. 2018, 35, 944-953. [CrossRef]

8. Fratto, V.; Sava, M.G.; Krivace, G.J. The impact of an online homework management system on student performance and course satisfaction in introductory financial accounting. Int. J. Inf. Commun. Technol. Educ. 2016, 12, 76-87. [CrossRef]

9. Magalhães, P.; Ferreira, D.; Cunha, J.; Rosário, P. Online vs traditional homework: A systematic review on the benefits to students' performance. Comput. Educ. 2020, 152, 103869. [CrossRef]

10. Sosin, K.; Blecha, B.; Agarwal, R.; Bartlett, R.; Daniel, J. Efficiency in the Use of Technology in Economic Education: Some Preliminary Results. Am. Econ. Rev. 2004, 94, 253-258. [CrossRef]

11. Ben Youssef, A.; Dahmani, M.; Omrani, N. Information technologies, students' e-skills and diversity of learning process. Educ. Inf. Technol. 2015, 20, 141-159. [CrossRef]

12. Castillo-Merino, D.; Serradell-Lopez, E.; Vilaseca-Requena, J. Usage des technologies de l'information et de la communication dans l'enseignement supérieur: Une analyse des performances des étudiants en e-learning dans la région catalane. Réseaux $\mathbf{2 0 0 9}$ 27, 55-80. [CrossRef] 
13. Hämäläinen, R.; De Wever, B.; Nissinen, K.; Cincinnato, S. What makes the difference-PIAAC as a resource for understanding the problem-solving skills of Europe's higher-education adults. Comput. Educ. 2019, 129, 27-36. [CrossRef]

14. Hinrichsen, J.; Coombs, A. The five resources of critical digital literacy: A framework for curriculum integration. Res. Learn. Technol. 2013, 21, 1-16. [CrossRef]

15. van Deursen, A.J.A.M.; van Dijk, J.A.G.M.; ten Klooster, P.M. Increasing inequalities in what we do online: A longitudinal cross-sectional analysis of Internet activities among the Dutch population (2010 to 2013) over gender, age, education, and income. Telemat. Inform. 2015, 32, 259-272. [CrossRef]

16. Samaha, M.; Hawi, N.S. Relationships among smartphone addiction, stress, academic performance, and satisfaction with life Comput. Human Behav. 2016, 57, 321-325. [CrossRef]

17. Vigdor, J.L.; Ladd, H.F.; Martinez, E. Scaling the Digital Divide: Home Computer Technology and Student Achievement. Econ. Inq. 2014, 52, 1103-1119. [CrossRef]

18. Krasilnikov, A.A.; Semenova, M. Do Social Networks Help to Improve Student Academic Performance? The Case of Vk.com and Russian Students. Econ. Bull. 2014, 34, 718-733.

19. Fuchs, T.; Woessmann, L. Computers and Student Learning: Bivariate and Multivariate Evidence on the Availability and Use of Computers at Home and at School. Bruss. Econ. Rev. 2004, 47, 359-385.

20. Fernández-Ferrer, M.; Cano, E. The influence of the internet for pedagogical innovation: Using twitter to promote online collaborative learning. Int. J. Educ. Technol. High Educ. 2016, 13, 22. [CrossRef]

21. Demirci, N. Web-based vs. paper-based homework to evaluate students' performance in introductory physics courses and students' perceptions: Two years' experience. Int. J. E-Learn. 2010, 9, 27-49.

22. Erdogdu, F.; Erdogdu, E. The impact of access to ICT, student background and school/home environment on the academic success of students in Turkey: An international comparative analysis. Comput. Educ. 2015, 82, 26-49. [CrossRef]

23. Banerjee, A.V.; Cole, S.; Duflo, E.; Linden, L. Remedying Education: Evidence from two randomized experiments in India. Q. J. Econ. 2007, 122, 1235-1264. [CrossRef]

24. Castillo-Merino, D.; Serradell-López, E. An analysis of the determinants of students' performance in e-learning. Comput. Human Behav. 2014, 30, 476-484. [CrossRef]

25. Power, E.; Partridge, H.; O'Sullivan, C.; Kek, M.Y.C.A. Integrated 'one-stop' support for student success: Recommendations from a regional university case study. High. Educ. Res. Dev. 2020, 39, 561-576. [CrossRef]

26. Julien, H.; Gross, M.; Latham, D. Survey of Information Literacy Instructional Practices in U.S. Academic Libraries. Coll. Res. Libr. 2018, 79, 179-199. [CrossRef]

27. Agasisti, T.; Soncin, M. Higher education in troubled times: On the impact of Covid-19 in Italy. Stud. High. Educ. 2021, 46, 86-95. [CrossRef]

28. Vega-Hernández, M.C.; Patino-Alonso, M.C.; Galindo-Villardón, M.P. Multivariate characterization of university students using the ICT for learning. Comput. Educ. 2018, 121, 124-130. [CrossRef]

29. Lundberg, J.; Dahmani, M.; Castillo-Merino, D. Do online students perform better than face-to-face students? Reflexions and a short review of some empirical findings. RUSC Univ. Knowl. Soc. J. 2008, 5, 35-44.

30. Lundin, J.; Magnusson, M. Collaborative learning in mobile work. J. Comput. Assist. Learn. 2003, 19, 273-283. [CrossRef]

31. Alhabeeb, A.; Rowley, J. E-learning critical success factors: Comparing perspectives from academic staff and students. Comput. Educ. 2018, 127, 1-12. [CrossRef]

32. Han, H.; Moon, H.; Lee, H. Physical classroom environment affects students' satisfaction: Attitude and quality as mediators. Soc. Behav. Personal. 2019, 47, 1-10. [CrossRef]

33. Fairlie, R.W. The effects of home access to technology on computer skills: Evidence from a field experiment. Inf. Econ. Policy 2012, 24, 243-253. [CrossRef]

34. Lněnička, M.; Nikiforova, A.; Saxena, S.; Singh, P. Investigation into the adoption of open government data among students: The behavioural intention-based comparative analysis of three countries. Aslib J. Inf. Manag. 2022, ahead-of-print. [CrossRef]

35. Lněnička, M.; Machova, R.; Volejníková, J.; Linhartová, V.; Knezackova, R.; Hub, M. Enhancing transparency through open government data: The case of data portals and their features and capabilities. Online Inf. Rev. 2021, 45, 1021-1038. [CrossRef]

36. Nikiforova, A.; Lnenicka, M. A multi-perspective knowledge-driven approach for analysis of the demand side of the Open Government Data portal. Gov. Inf. Q. 2021, 38, 101622. [CrossRef]

37. Sharpe, A. Ten Productivity Puzzles Facing Researchers. Int. Product. Monit. 2004, 9, 15-24.

38. Agarwal, R.; Day, A.E. The impact of the internet on economic education. J. Econ. Educ. 1998, 29, 99-110. [CrossRef]

39. Ball, S.B.; Eckel, C.C.; Rojas, C. Technology Improves Learning in Large Principles of Economics Classes: Using Our WITS. Am. Econ. Rev. 2006, 96, 442-446. [CrossRef]

40. Tadesse, T.; Gillies, R.M.; Campbell, C. Assessing the dimensionality and educational impacts integrated ICT literacy in the higher education context. Aust. J. Educ. Tech. 2018, 34, 88-101. [CrossRef]

41. Lee, S.W.-Y.; Tsai, C.-C. Students' perceptions of collaboration, self-regulated learning, and information seeking in the context of internet-based learning and traditional learning. Comput. Hum. Behav. 2011, 27, 905-914. [CrossRef]

42. Buasuwan, P. Rethinking Thai higher education for Thailand 4.0. Asian Educ. Dev. Stud. 2018, 7, 157-173. [CrossRef]

43. Harmon, O.R.; Tomolonis, P. The effects of using Facebook as a discussion forum in an online principles of economics course: Results of a randomized controlled trial. Int. Rev. Econ. Educ. 2019, 30, 100157. [CrossRef] 
44. Pezzino, M. Online assessment, adaptive feedback, and the importance of visual learning for students. The advantages, with a few caveats, of using MapleTA. Int. Rev. Econ. Educ. 2018, 28, 11-28. [CrossRef]

45. Vaughan, N.; Cloutier, D. Evaluating a blended degree program through the use of the NSSE framework. Br. J. Educ. Technol. 2017, 48, 1176-1187. [CrossRef]

46. Wuthisatian, R.; Thanetsunthorn, N. Teaching macroeconomics with data: Materials for enhancing students' quantitative skills. Int. Rev. Econ. Educ. 2019, 30, 100151. [CrossRef]

47. Cao, X.; Masood, A.; Luqman, A.; Ali, A. Excessive use of mobile social networking sites and poor academic performance: Antecedents and consequences from the stressor-strain-outcome perspective. Comput. Hum. Behav. 2018, 85, 163-174. [CrossRef]

48. Giunchiglia, F.; Zeni, M.; Gobbi, E.; Bignotti, E.; Bison, I. Mobile social media usage and academic performance. Comput. Hum. Behav. 2018, 82, 177-185. [CrossRef]

49. Gui, M.; Argentin, G. Digital skills of internet natives: Different forms of digital literacy in a random sample of northern Italian high school students. New Media Soc. 2011, 13, 963-980. [CrossRef]

50. Mengual-Andrés, S.; Roig-Vila, R.; Mira, J.B. Delphi study for the design and validation of a questionnaire about digital competences in higher education. Int. J. Educ. Technol. High Educ. 2016, 13, 12. [CrossRef]

51. van Deursen, A.J.A.M.; Helsper, E.J.; Eynon, R. Development and validation of the internet skills scale (ISS). Inf. Commun. Soc. 2016, 19, 804-823. [CrossRef]

52. van Laar, E.; van Deursen, A.J.A.M.; van Dijk, J.A.G.M.; De Haan, J. The relation between 21st-century skills and digital skills: A systematic literature review. Comput. Hum. Behav. 2017, 72, 577-588. [CrossRef]

53. Du, J.T.; Evans, N. Academic users' information searching on research topics: Characteristics of research tasks and search strategies. J. Acad. Libr. 2011, 37, 299-306. [CrossRef]

54. Calafiore, P.; Damianov, D.S. The effect of time spent online on student achievement in online economics and finance courses. $J$. Econ. Educ. 2011, 42, 209-223. [CrossRef]

55. Attewell, P.; Battle, J. Home computers and school performance. Inf. Soc. 1999, 15, 1-10.

56. Wurst, C.; Smarkola, C.; Gaffney, M.A. Ubiquitous laptop usage in higher education: Effects on student achievement, student satisfaction, and constructivist measures in honors and traditional classrooms. Comput. Educ. 2008, 51, 1766-1783. [CrossRef]

57. Chen, J.; Lin, T.F. The benefit of providing face-to-face lectures in online learning microeconomics courses: Evi-dence from a regression discontinuity design experiment. Econ. Bull. 2016, 36, 2094-2116.

58. Dyson, B.; Vickers, K.; Turtle, J.; Cowan, S.; Tassone, A. Evaluating the use of Facebook to increase student engagement and understanding in lecture-based classes. High. Educ. 2015, 69, 303-313. [CrossRef]

59. Ben Youssef, A.; Hadhri, W. Les dynamiques d'usage des technologies de l'information et de la communication par les enseignants universitaires. Reseaux 2009, 27, 23-54. [CrossRef]

60. Dahmani, M. Determinants of the Digital Divide among French Higher Education Teachers. South Asian J. Soc. Stud. Econ. 2021, 12, 10-28. [CrossRef]

61. Ben Youssef, A.; Ragni, L. Uses of Information and Communication Technologies in Europe's Higher Education Institutions: From Digital Divides to Digital Trajectories. RUSC Univ. Knowl. Soc. J. 2008, 5, 72-84. [CrossRef]

62. Greene, W.H. Econometric Analysis, 8th ed.; Pearson: New York, NY, USA, 2018.

63. Wooldridge, J.M. Econometric Analysis of Cross Section and Panel Data, 2nd ed.; MIT Press: Cambridge, MA, USA, 2010.

64. Tabachnick, B.G.; Fidell, L.S. Using Multivariate Statistics, 5th ed.; Allyn and Bacon: New York, NY, USA, 2007.

65. Hair, J.F.; Black, W.C.; Babin, B.J.; Anderson, R.E.; Tatham, R.L. Multivariate Data Analysis, 6th ed.; Pearson: Upper Saddle River, NJ, USA, 2006.

66. Nunnally, J.C.; Bernstein, I.H. Psychometric Theory, 3th ed.; McGraw Hill: New York, NY, USA, 1994.

67. Celeux, G.; Diday, E.; Govaert, G.; Lechevallier, Y.; Ralambondrainy, H. Classification Automatique des Donnees; Dunod: Paris, France, 1989.

68. Han, K.; Kamber, M.; Pei, J. Data Mining Concepts and Techniques, 3rd ed.; Morgan Kaufmann, Elsevier Inc.: Amsterdam, The Netherlands, 2012.

69. Fairlie, R.W.; Bahr, P.R. The effects of computers and acquired skills on earnings, employment and college enrollment: Evidence from a field experiment and California UI earnings records. Econ. Educ. Rev. 2018, 63, 51-63. [CrossRef]

70. Gil-Flores, J.; Rodríguez-Santero, J.; Torres-Gordillo, J.-J. Factors that explain the use of ICT in secondary-education classrooms: The role of teacher characteristics and school infrastructure. Comput. Hum. Behav. 2017, 68, 441-449. [CrossRef]

71. Kuo, Y.-C.; Brian Belland, B.R.; Kuo, Y.-T. Learning through Blogging: Students' Perspectives in Collaborative Blog-Enhanced Learning Communities. J. Educ. Technol. Soc. 2017, 20, 37-50.

72. Rubach, C.; Lazarides, R. Addressing 21st-century digital skills in schools-Development and validation of an instrument to measure teachers' basic ICT competence beliefs. Comput. Hum. Behav. 2021, 118, 106636. [CrossRef]

73. Flavin, M.A. Technology-enhanced learning and higher education. Oxf. Rev. Econ. Policy 2016, 32, 632-645. [CrossRef]

74. Greene, J.; Yu, S.; Copeland, D. Measuring critical components of digital literacy and their relationships with learning. Comput. Educ. 2014, 76, 55-69. [CrossRef]

75. McGrew, S.; Breakstone, J.; Ortega, T.; Smith, M.; Wineburg, S. Can Students Evaluate Online Sources? Learning From Assessments of Civic Online Reasoning. Theor. Res. Soc. Educ. 2018, 46, 165-193. [CrossRef] 